\title{
KEBEBE: THE TRADITIONAL FOOD IN THE SUB-DISTRICT OF LENGGONG, PERAK
}

\author{
Munira Saaidin \\ Faculty of Business \& Technology, UNITAR International University, Malaysia \\ Erdaizzati Mohd Som \\ UNITAR College, UNITAR International University, Malaysia \\ Nur Juliana Azhari \\ School of Culinary Arts, UNITAR International University, Malaysia \\ Annis Jamaluddin \\ School of Culinary Arts, UNITAR International University, Malaysia \\ W. Eddie Azlie W. Mohd Asri \\ School of Culinary Arts, UNITAR International University, Malaysia \\ Mislan Nenin \\ Faculty of Business \& Technology, UNITAR International University, Malaysia
}

\begin{abstract}
This is an investigative study on Kebebe which had been identified as one of the traditional foods in the sub-district of Lenggong in Hulu Perak. It addressed the need to get a better understanding on the food itself, its origin, the ingredients, the methods of preparation and cooking, and the manner in which it is served and consumed. It also looked into the level of knowledge the community members have on Kebebe. Information on the food is derived collectively from five experts and feedback from 46 respondents which comprised of youths and community members of varying age group were gathered to determine the extent of knowledge the community have on Kebebe. Results from the study indicated that there was quite a general consensus on the detail of the foodways, and generally the respondents had some knowledge on the ingredients, the methods of preparation and others. Overall, the study had been able to provide important information that could help in the preservation of Kebebe as a traditional food and a culinary heritage of the community of that area.
\end{abstract}


Key words: Kebebe, traditional food, ingredients, cooking tools.

Cite this Article: Munira Saaidin, Erdaizzati Mohd Som, Nur Juliana Azhari, Annis Jamaluddin, W. Eddie Azlie W. Mohd Asri and Mislan Nenin, Kebebe: The Traditional Food in the Sub-District of Lenggong, Perak, International Journal of Management, 11(12), 2020, pp 470-482.

http://iaeme.com/Home/issue/IJM?Volume $=11 \&$ Issue $=12$

\section{INTRODUCTION}

Traditional foods played a major role in the traditions of different cultures and regions for thousands of years including foods that had been consumed locally and regionally for an extended time period. Preserving Traditional Food Knowledge (TFK) had received greater concern among the older generations as indicated by the Malaysian Cultural Association of the Ministry of Information, Communication and Culture, and other government agencies. Some ethnic groups were reported not only facing the deskilling issues related to domestic cooking skills, but had begun to lose the traditional food culture due to the inability of the elder generations to pass down the traditional cooking knowledge to the younger generations (Stringer, 2009; Bowen and Devine, 2011). Kwik (2008) stated that the distinct expressions of taste and place were facing a continuity gap when traditional food knowledge had not been passed forward, but rather sidelined as abstract, historical concept.

This study addressed the need for the development of knowledge on traditional foods, their origins, the special ingredients, and the specialized methods of preparation. The findings from this study could contribute towards the preservation of traditional foods in the study area. Food knowledge can be obtained through several ways but the most common is learned from mother and family relatives when it involved family traditional foods. Some others may learn from community members when it is involves a modern or the latest food trends (Sharif, et al, 2014).

This study aimed at investigating empirically if there were distinct types of the traditional foods in the Hulu Perak District and if there were common agreeable methods of preparation and consumption among the traditional food experts. Thus, the specific objectives of the study were to:

- Identify the traditional foods in area of study which was the Hulu Perak District.

- Examine the basic ingredients of the identified traditional foods.

- Understand the common methods of preparation and cooking of the identified traditional foods in Hulu Perak District.

- Determining the level of foodways knowledge on the identified traditional foods amongst the youths/community in the Hulu Perak District.

\section{LITERATURE OVERVIEW}

Traditional food is a food with a specific feature or features which distinguish it clearly from other similar products of the same category in terms of the use of "traditional ingredients" (raw material of primary products) or "traditional composition" or "traditional type of production and/or processing method (CENM). According to Lestari (2014) traditional foods are foods and beverages commonly consumed by a particular community, with distinctive flavor that is accepted by the community.

The concept of traditional food knowledge integrates several academic disciplines such as social, cultural, and nutritional anthropology, human ecology, agriculture, population health, family studies, community development, and education, among others. By conducting this 
study, traditional food knowledge can be viewed from various angles to understand the many implications for the ecosystem health of a community (Kwik, 2008). From other study, (Sharif \& Fadillah, 2011) mentioned through from this knowledge traditional food knowledge it is finding that there has a several factors influencing the level of traditional food knowledge such as formal learning, informal learning and social lifestyle. Blending these perspectives will also provide opportunities to find innovative approaches to appreciating and passing on traditional food knowledge for the sake of health promotion and community development in specific geographic areas (Kwik, 2008). Traditional food knowledge can be a means of asserting cultural identity, particularly for specific cultural groups; transmitting this knowledge may contribute to personal skills that relate to food security and personal nutrition and enhanced community capacity (Md Nor, et al, 2013).

Traditional food through its preparation and consumption are one of the best ways to understand a culture and ethnic identity (Verbeke \& Lopez, 2005). In Malaysia, the culinary identity was generally an adaptation of traditions from its Malay, Chinese, Indian, Indonesian, and the ethnic Bornean background; and with some heavy to light influences from Thai, Portuguese, Dutch, and British cuisines, to name a few. This had resulted in a variety of flavors, which thus made Malaysian cuisine highly complex and diverse. In addition, the cuisine had also being influenced by the regional differences of the 14 states of the country. For example, Nasi Kerabu was originally from Kelantan, Pasembor was from Penang, Telur Pindang was from Johor.

A study by the Centre for Indigenous Peoples' Nutrition and Environment from the McGill University, in its article on Nutritional Benefits of Traditional Food, it indicated that "foods from land and sea once provided everything for people. Today, a mix of market and traditional food was common for most people, but traditional food remained an important source of many nutrients". The findings from its study showed that on days when people ate both traditional and market foods, their diets were better than when they ate only market food. Among the benefits of traditional foods were less calories, less saturated fat, more iron, zinc, calcium and vitamin A, and it strengthened cultural capacity and well-being

Culinary and culture tourism or food tourism included the exploration of food as the purpose of tourism (Long 2004; and Gary and Albala, 2007) It had now been considered a vital component of the tourism experience. Dining out had become common amongst tourists and "food was believed to be ranked alongside climate, accommodation, and scenery" in its importance to tourists (McKercher, Okumus and Okumus, 2008)

\section{MATERIALS AND METHODS}

This study utilized the qualitative approach to identify the traditional foods and determine methods of preparation, cooking, and serving the traditional foods. The information gathered through this approach would provide a further understanding of the process and the reasons for such perceptions. The quantitative approach had also been used through the process of examining the level of foodways knowledge on the identified traditional foods amongst the youths/community of Lenggong area.

The selected area of study was the sub-district of Lenggong, in the district of Hulu Perak. This particular area is interesting because it is located in the proximity of the border to the country of Thailand to the north. It is a large area which covers about 6,500 square kilometers and the major ethnic groups of the area were the Malays, and the Indigenous people or Orang Asli. The Malaysian Chinese and Malaysian Indians comprised of a very small percentage of the population. 
There are two groups of respondents in this study:

Group 1: Five (5) Traditional Food Experts

Process of selecting the food experts:

Step 1: A focus group which comprised of 7 prominent individuals from the Hulu Perak district was asked on the popular traditional food of the area.

Step 2: The head of communities of Hulu Perak were contacted and were requested to recommend a few names of the traditional food experts in their communities.

Step 3: All prospective traditional food experts were contacted via telephone for permission to conduct the interviews and the convenient date, times, and venues for the interviews

Step 4: All traditional food experts (which may include traditional food restaurants owners, food traditional entrepreneurs, chefs, cooks and selected senior citizens of the district) were asked to name all the traditional foods, and from that list.

Step 5: Among the traditional food experts, 5 experts were finally selected based on the positive responses on the traditional food: Kebebe.

Group 2: Forty-six (46) Respondents (youths) on the questionnaires

\section{Process of selecting the youth respondents:}

Step 1: Characteristics: those youths aged between 18 and 40 years and those 50 and over.

Step 2: Initial question asked: Can you name all the traditional foods showed? Those who could not name any was eliminated from the list.

Step 3:Questionnaires were then distributed to those who answered affirmatively.

Primary Data was collected via Face-to-face discussions and with the selected traditional food experts. The discussions and interviews were conducted with the guide of a set of semistructured, open-ended questions that were developed to derive significant information on the identified traditional foods. Information were collected via observations on the preparation and cooking of the traditional food by the experts. The following 8 open-ended questions were directed at the 5 traditional foods experts. The purpose of each question was to derive a consensus on the responses.

\begin{tabular}{|l|l|}
\hline Question No. & \multicolumn{1}{c|}{ Items } \\
\hline 1 & What are the main ingredients to prepare the product? \\
\hline 2 & $\begin{array}{l}\text { How is the food being prepared? Why is it being prepared in that } \\
\text { way? }\end{array}$ \\
\hline 3 & What is the equipment used to prepare the product? \\
\hline 4 & Where the product originates from? \\
\hline 5 & In what occasion the product will be served to the guests? \\
\hline 6 & To whom the food is prepared? Why? \\
\hline 7 & How the food is served to the guest? \\
\hline 8 & What the other foods can be served with the product? \\
\hline
\end{tabular}

A self-administered, structured questionnaire were distributed to the youths/community in the area of Hulu Perak. The questionnaire was aimed at finding out the demographic profiles of the respondents, their overall level of knowledge on traditional foods, and their level of knowledge on the 3 traditional foods of Hulu Perak.

A 5-point Likert-like scale was used to measure the extent of the respondent knowledge on the Traditional Food. 
Munira Saaidin, Erdaizzati Mohd Som, Nur Juliana Azhari, Annis Jamaluddin,

W. Eddie Azlie W. Mohd Asri and Mislan Nenin

\begin{tabular}{|c|c|c|c|c|}
\hline $\begin{array}{c}\text { Strongly } \\
\text { Disagree }\end{array}$ & Disagree & $\begin{array}{c}\text { Slightly } \\
\text { Disagree }\end{array}$ & Agree & $\begin{array}{c}\text { Strongly } \\
\text { Agree }\end{array}$ \\
\hline 1 & 2 & 3 & 4 & 5 \\
\hline
\end{tabular}

The following scale was used to determine the summary of findings on the overall level of knowledge and the specific knowledge on the 3 traditional foods:

\begin{tabular}{|l|l|l|l|l|}
\hline \multicolumn{1}{|c|}{$\begin{array}{c}\text { Strongly } \\
\text { Disagree }\end{array}$} & Disagree & \multicolumn{1}{c|}{$\begin{array}{c}\text { Slightly } \\
\text { Disagree }\end{array}$} & \multicolumn{1}{|c|}{ Agree } & \multicolumn{1}{c|}{$\begin{array}{c}\text { Strongly } \\
\text { Agree }\end{array}$} \\
\hline $\begin{array}{l}\text { No } \\
\text { Knowledge }\end{array}$ & $\begin{array}{l}\text { Hardly Any } \\
\text { Knowledge }\end{array}$ & $\begin{array}{l}\text { Slight } \\
\text { Knowledge }\end{array}$ & $\begin{array}{l}\text { Partial } \\
\text { (Some) } \\
\text { Knowledge }\end{array}$ & $\begin{array}{l}\text { Full } \\
\text { Knowledge }\end{array}$ \\
\hline $1.00-1.99$ & $2.00-2.99$ & $3.00-3.99$ & $4.00-4.99$ & 5.00 \\
\hline
\end{tabular}

\section{STUDY FINDINGS}

The study findings are presented in two parts:

- Detail on the aspects of Kebebe, and

- Level of Knowledge on Kebebe as a Traditional Food by the community in the Lenggong area.

\subsection{Detail on the aspects of Kebebe as a Traditional Food}

The Findings were based on responses on the following factors:

- The main ingredients used in the preparation.

- The method in which the food is being prepared and the reasons for preparing that way.

- The equipment used to prepare the product.

- The origin of product.

- The occasion the product will be served to the guests.

- For whom the food is prepared and the reasons.

- The ways the food is served to the guest.

- Other foods that can be served with product.

\subsubsection{FACTOR 1: The main ingredients used in the preparation of Kebebe}

Table 1 indicated the detailed responses by the 5 experts on Kebebe and on the common ingredients used in making of Kebebe:

On a consensus basis, the following main ingredients and their preparation methods as suggested by the 5 experts

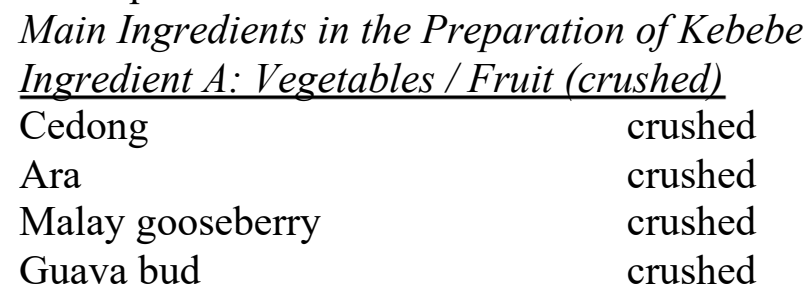

Ingredient B: Vegetables / Fruit (peeled and finely sliced) Banana male flower bud peeled and finely sliced Mangga Telur Pineapple peeled and finely sliced peeled and finely sliced 
Kebebe: The Traditional Food in the Sub-District of Lenggong, Perak

Ingredient C: Vegetables / Fruit (peeled, finely sliced and crushed)

Jackfruit peeled, finely sliced and crushed

Ingredient D (bruised)

Bird's eye chillies bruised

Dried prawn (shrimp) paste bruised

$\underline{\text { Seasoning }}$

Salt to taste

Palm sugar to taste

Table 1 Main Ingredients in Kebebe

\begin{tabular}{|l|l|}
\hline Expert 1 & $\begin{array}{l}\text { fried coconut paste, young jackfruit peeled and finely sliced, guava bud, } \\
\text { asam belimbing,banana male flower bud, buah chedong, buah ara, wild fruit, } \\
\text { chillies, shrimp paste, mango and cermai }\end{array}$ \\
\hline Expert 2 & $\begin{array}{l}\text { bird's eyes chilies, salt, shrimp paste, sour star fruit, banana bud (banana lower), } \\
\text { young jackfruit like small papaya size, fried coconut paste (kerisik), } \\
\text { sugar }\end{array}$ \\
\hline Expert 3 & $\begin{array}{l}\text { young guava, banana bud (banana flower), chendong fruit (red in color), asam } \\
\text { belimbing.prawn paste, bird's eyes chilies, salt, fried coconut paste.sugar } \\
\text { (optional) }\end{array}$ \\
\hline Expert 4 & $\begin{array}{l}\text { prawn paste,bird's eyes chilies, banana bud (banana flower), young mango, } \\
\text { ara fruit, cermai,fried coconut paste, (rempah masak / nyior rendang / kerisik). } \\
\text { any fruits available in surrounding area (optional) }\end{array}$ \\
\hline Expert 5 & $\begin{array}{l}\text { malay gooseberry, bidara, mango, banana bud, salt, hrimp,paste, banana, belacan, } \\
\text { bird's eye chillies.unrippen fruits,belimbing buloh,salt. }\end{array}$ \\
\hline
\end{tabular}

\subsubsection{FACTOR 2: The methods in which Kebebe is being prepared and the reasons for preparing that way.}

Table 2 indicated the methods in which Kebebe is prepared by each of the 5 experts:

Information extracted from the 5 experts indicated the following common methods in preparing Kebebe:

\section{Method of Cooking:}

- Bruised a bird's eye chilies and salt using a large wood mortar and pestle.

- Once bruised, combined the ingredient with dried prawn (shrimp) paste and grind into a fine paste.

- Add in jack fruit first among other fruits due to its hard texture and crushed.

- Add all remaining fruits in ingredient $\mathrm{A}$ in sequence and slowly starting with ara, cedong, guava bud, malay gooseberry and crushed.

- Once crushed, add all remaining ingredient $B$, in sequence starting from male flowers bud, manga telur and pineapple to be the last one due to its soft and watery texture.

- Season again with salt and sugar before serving.

- Serve the kebebe in banana outer bract. 
Munira Saaidin, Erdaizzati Mohd Som, Nur Juliana Azhari, Annis Jamaluddin,

W. Eddie Azlie W. Mohd Asri and Mislan Nenin

Table 2 Methods of Preparation of Kebebe

\begin{tabular}{|c|c|}
\hline Expert 1 & $\begin{array}{l}\text { 1. Peel the skin and cut it into fine size. } \\
\text { 2. Clean and strain the water. } \\
\text { 3. Pound together with bird's eye chilli, shrimp paste and salt. } \\
\text { add in asam belimbing } \\
\text { (The reason to add in asam belimbing first because to avoid oxidation on the } \\
\text { fruits before other fruits) } \\
\text { 4. Add young jackfruit, guava and banana bud. } \\
\text { 5.Add in the coconut paste. } \\
\text { 6.Add in sugar and salt. Upon individual taste. } \\
\text { * Most important to have the hot taste in kebebe. }\end{array}$ \\
\hline Expert 2 & $\begin{array}{l}\text { 1.Pounded together in the wood mortar. Bird's eyes chilies, salt, prawn paste } \\
\text { 2.Removed the young jackfruit skin and the core } \\
\text { 3. Shredded or cut it into two finger sizes } \\
\text { 4.add in the banana bud that already cut into fine } \\
\text { 5. Mixed together with the jackfruit in the wood mortar. } \\
\text { 6.Add in asam belimbing and the coconut paste to bring the smell out. *The } \\
\text { coconut paste must be the home made. } \\
\text { 7.The asam belimbing to add later not together with other ingredients and } \\
\text { pounded it until everything crushed into small pieces. }\end{array}$ \\
\hline Expert 3 & $\begin{array}{l}\text { 1. All ingredients mixed and pound until it is fine (Lait or lumat). } \\
\text { 2. Add in salt, bird's eye chillies } \\
\text { 3. Add in shrimp paste. No need to cut into fine shape. } \\
\text { *Kebebe not suitable to pound in small mortar. } \\
\text { *The texture must be hard coarse the only it tastes nice and juicy. } \\
\text { *Kebebe is made during paddy occasion } \\
\text { *use leg mortar } \\
\text { *Also made after preparing the kerisik during the kenduri. } \\
\text { *Kebebe only serve for the people who helped for kenduri. }\end{array}$ \\
\hline Expert 4 & $\begin{array}{l}\text { 1.Pounded all the ingredients in the wooden mortal } \\
* \text { where there is a balance of fried coconut paste stick in the mortar will mixed } \\
\text { together with the mixture. } \\
\text { 2. Pounded the fried coconut paste } \\
* \text { used the balance of the fried coconut paste mixed together with all the fruits } \\
\text { available and other ingredients } \\
\text { 3.Pounded it together. } \\
\text { * During the wedding festive the people who work at the back of the house } \\
\text { (penanggah) } \\
\text { * for those who (penanggah) will shared the Kebebe }\end{array}$ \\
\hline Expert 5 & $\begin{array}{l}\text { 1. Fine cut all the fruits and crushed with the wood mortar. } \\
\text { 2.Add in shrimp paste and salt. } \\
\text { *There will be few people to do this job. } \\
\text { *Normally it is prepared during kenduri or known as rewang. } \\
\text { * Nowadays young generations have various choices of food as compare to the old } \\
\text { time. }\end{array}$ \\
\hline
\end{tabular}

\subsubsection{FACTOR 3: The equipment used to prepare Kebebe}

Table 3 listed the equipment that were used to make Kebebe by the 5 experts: 


\section{Tools/Utensils used in making Kebebe}

Mortar made from stone, wood or iron, Mortar by using leg known as hindik.

Table 3 Equipment/Tools used in Preparing Kebebe

\begin{tabular}{|l|l|}
\hline Expert 1 & Mortar made from stone, wood or iron. \\
\hline Expert 2 & Mortar / steel mortar / stone mortar." \\
\hline Expert 3 & $\begin{array}{l}\text { Mortar by using leg. Wood mortar is used for ensuring the ingredient are crushed finely } \\
\text { before adding in salt, shrimp paste, bird's eye chilies. All the fruits need not to cut into } \\
\text { fine shape just add the whole fruits into the mortar. } \\
\text { *Have to use big mortar because there are many to serve for. But if made for own self } \\
\text { enough by using the stone mortar." }\end{array}$ \\
\hline Expert 4 & $\begin{array}{l}\text { Use wood mortar. Can prepared in a big portion. } \\
\text { Usually prepared by woman." }\end{array}$ \\
\hline Expert 5 & $\begin{array}{l}\text { The method is to crush by using wood mortar. } \\
\text { In the position of standing, the long stick (alu) and the mortar is used to mash the } \\
\text { * The sitting down position is not suitable. } \\
\text { Wooden mortar by using leg to mix the ingredient well. } \\
\text { The leg mortar known as hindik. } \\
\text { * should not use stone mortar because the speed and production will be minimal. *fruits } \\
\text { must be cut in small and fine cut before mixed into the mortar. *If use whole fruit, it may } \\
\text { consume more time }\end{array}$ \\
\hline
\end{tabular}

\subsubsection{FACTOR 4: The origin of Kebebe}

The 5 Kebebe food experts indicated where Kebebe originated from in Table 4.

The experts agreed that Kebebe originate from Kampung Luat, Patani, in the southern part of Thailand. The experts indicated that they could traced back the origin as far back as great grandparents. Food heritage which is associated with classical and traditional foods which are continuously practicing by all generations without major altering of the original flavours (Wahid, Mohamed, \& Sirat 2009). Food heritage can be reflected from the environment history, belief, ideology and food technology of society in an era or period of time.

Table 4 Origin of Kebebe

\begin{tabular}{|l|l|}
\hline Expert 1 & $\begin{array}{l}\text { From ancestor when I was still young during that time. Patani from mother side } \\
\text { while Penang from my dad side. }\end{array}$ \\
\hline Expert 2 & The recipe comes from great grandparents. \\
\hline Expert 3 & $\begin{array}{l}\text { Kebebe originally created from Pattani including the story of this Kampung Luat. } \\
\text { Kebebe is Pattani language. }\end{array}$ \\
\hline Expert 4 & Kebebe / pincuk come from Pattani. \\
\hline Expert 5 & $\begin{array}{l}\text { The origin of kebebe I do not know from where but one thing for sure, it is from } \\
\text { the old people long time ago. }\end{array}$ \\
\hline
\end{tabular}

\subsubsection{FACTOR 5: The occasion Kebebe would be served to the guests}

The 5 experts were asked on the specific occasions when Kebebe would be served.

\section{Occasions when Kebebe is served}

This question that tracked on the occasion Kebebe should be served. Similar viewed were given by the experts during the interviewed session. Kebebe would normally be by the ladies prior to or on any religious occasions or events. Being traditionally made using a leg mortar, Kebebe would be viewed as a symbolized of appreciation and gratitude for the volunteers. In the old days, many Malay dishes were coconut based. This fact conformed that it would take 
more than 40 numbers of coconut needed for any religious occasion. The excess coconut in the leg mortar would then be used to prepare Kebebe so as to avoid any wastage.

Table 5: Occasion Kebebe will be Served to the Guests

\begin{tabular}{|l|l|}
\hline Expert 1 & $\begin{array}{l}\text { Prepare during kenduri only when people preparing coconut paste with } 40-50 \\
\text { numbers of coconut. } \\
\text { Usually use the waste in the mortar to make kebebe." }\end{array}$ \\
\hline Expert 2 & $\begin{array}{l}\text { You can prepare it anytime when you feel want to eat. } \\
\text { But usually during kenduri, } \\
\text { People prepare kerabu pucuk paku or any types of kerabu (pechok)." }\end{array}$ \\
\hline Expert 3 & Usually made before the kenduri. \\
\hline Expert 4 & $\begin{array}{l}\text { Normally the ladies will prepare the coconut paste and right after preparing the } \\
\text { coconut paste, } \\
\text { They will make the kebebe and serve for the volunteer people. } \\
\text { When there is kenduri, there will be kebebe serve too." }\end{array}$ \\
\hline Expert 5 & $\begin{array}{l}\text { Kenduri or any occasion in the village. } \\
\text { Usually kebebe will be prepared when there is a preparation of coconut paste for } \\
\text { kenduri. } \\
\text { Normally they will use the leg mortar. }\end{array}$ \\
\hline
\end{tabular}

\subsubsection{FACTOR 6: For whom Kebebe is prepared and the reasons for the preparation}

The 5 food experts were asked for whom Kebebe is usually prepared and the reasons for preparing the dish: Table 6 indicated for whom Kebebe would be prepared for, and they were:

\section{Who prepare the Kebebe and for who}

For this question, the experts agreed that Kebebe had been commonly prepared and would always be part of their food in their daily life. Kebebe would not only be served for family consumption or during friends visit, but it would also be served during or prior to any occasion for all the volunteers as token of appreciation by the host. The food characteristics, value of uniqueness, practice and integrations are the elements that had been described as determinants of food heritage. Guerroro et al (2009) stated dimension of traditional foods consist of element of habit, natural, origin and locality. Habit and natural associated traditional food with something anchored in the past to present, transmitted from one generation to another of food that has been consumes from the past or existed for a long time that has always been part of the consumer's life.

Table 6 For whom and Reasons for Preparing Kebebe

\begin{tabular}{|l|l|}
\hline Expert 1 & kebebe is common and it is for anyone to consume. \\
\hline Expert 2 & $\begin{array}{l}\text { Kebebe was often prepared for family or during friends visit, however, to my } \\
\text { knowledge it was never been served in any occasion }\end{array}$ \\
\hline Expert 3 & $\begin{array}{l}\text { It is common to find kebebe in any occasion here, we mainly serve it to villagers } \\
\text { who helped in the occasion }\end{array}$ \\
\hline Expert 4 & $\begin{array}{l}\text { It is often in our community that kebebe was served prior to any kenduri and it } \\
\text { was mainly for villagers who helped during kenduri }\end{array}$ \\
\hline Expert 5 & $\begin{array}{l}\text { To my best knowledge, kebebe is not always served for any special occasion, } \\
\text { but if there is, it should be for those who helped during kenduri. }\end{array}$ \\
\hline
\end{tabular}




\subsubsection{FACTOR 7: The ways Kebebe is served to the guest}

The experts were asked to indicate the manner in which Kebebe would be served. Table 7 showed the similarities and differences in the responses

\section{Ways in which the food is served}

In respond to the question, the experts accepted that Kebebe would often be served in banana outer bract and coconut shell among the older generations with some complement pineapple leaves as a spoon. In the olden days. Since the locals were very poor, any container or tools would use as serving tool. However, nowadays it is more practical to use plates.

Table 7 How Kebebe is served

\begin{tabular}{|l|l|}
\hline Expert 1 & We always serves kebebe using banana outer bract. \\
\hline Expert 2 & $\begin{array}{l}\text { Normally to makes it tastier, kebebe is best serve by using banana outer bract. } \\
\text { However, for my family consumption, I prefer to use plate }\end{array}$ \\
\hline Expert 3 & $\begin{array}{l}\text { During emergency era, most people will use banana bract. But today, it is } \\
\text { relatively common to use plate. }\end{array}$ \\
\hline Expert 4 & $\begin{array}{l}\text { In the old Malay days, kebebe was commonly served using coconut shell and } \\
\text { pineapple leaves compliment as a spoon }\end{array}$ \\
\hline Expert 5 & $\begin{array}{l}\text { Those day, we were very poor, we grab any tools or container that we had in the } \\
\text { kitchen. Some of them even use banana bract or banana shell to serve kebebe }\end{array}$ \\
\hline
\end{tabular}

\subsubsection{FACTOR 8: Other foods can be served with Kebebe}

The food respondents were asked yo specify the other foods that could be served with Kebebe. The responses were indicated in Table 8.

\section{Other foods can be served with Kebebe}

In respond to the question, most of the experts indicated that, Kebebe would normally be $\mathrm{d}$ as a light dish and no other dish could be d together with Kebebe. Some sour-tasting traditional fruits such as cermai, jambu merah, pelam muda, asam belimbing would be used as the main ingredients. In the olden days the locals believe that Kebebe could also be used to make for those who are not feeling well or had fever and normally it would be served by itself.

Table 8 Other Foods that are Served together with Kebebe

\begin{tabular}{|l|l|}
\hline Expert 1 & Kebebe will served as single dishes,there is no other food accompanied." \\
\hline Expert 2 & "Kebebe can eat it immediately." \\
\hline Expert 3 & "Basically, kebebe will eat it as a light dish." \\
\hline Expert 4 & Basically, kebebe will eat it as a light dish." \\
\hline Expert 5 & Basically, kebebe will eat it as a light dish after completed main dish. \\
\hline
\end{tabular}

\subsection{Level of Knowledge on Kebebe as a Traditional Food by the community in the Lenggong area.}

\subsubsection{Partitioning of Gender with Level of Knowledge on Kebebe as the Traditional Food of Hulu Perak}

On the partitioning of gender with level of knowledge on Kebebe as the traditional food of Hulu Perak, the overall findings indicated that all the male and female respondents had some knowledge that (1) the jackfruit, banana, guava, pineapple, cermai, cedung, belimbing buluh and kelempong were some of the ingredients used in making Kebebe, (2) the basic ingredients in making Kebebe would usually be mixed together with shrimp paste and bird's eye chilies, (3) Kebebe was usually prepared with community working together in preparation for feast 
and iftar events, (4) the preparation of Kebebe would be more attractive when it was served in banana leaves and banana flower, and that (5) consuming Kebebe could overcome nauseating feeling other than its ability to cure lethargy, sickness and bitterness taste in the mouth. Thus, overall the results from the male and female respondents, as shown in Table 9, indicated that they had some knowledge on those 5 aspects.

Table 9 Partitioning of Gender with Level of Knowledge on KEBEBE as the Traditional Food

\begin{tabular}{|l|l|l|l|}
\hline \multirow{2}{*}{ NO. } & \multicolumn{1}{|c|}{ STATEMENT } & \multicolumn{1}{c|}{ AVERAGE SCORES } \\
\cline { 3 - 4 } & & \multicolumn{1}{|c|}{$\begin{array}{c}\text { Male } \\
\text { (19 Resp) }\end{array}$} & $\begin{array}{l}\text { Female } \\
\text { (27 Resp) }\end{array}$ \\
\hline 1 & $\begin{array}{l}\text { Jackfruit, banana, guava, pineapple, cermai, cedung, } \\
\text { belimbing buluh and kelempong are some of the } \\
\text { ingredients used in making Kebebe }\end{array}$ & $\begin{array}{l}\text { Some } \\
\text { K'ledge } \\
4.68\end{array}$ & $\begin{array}{l}\text { Some } \\
\text { K'ledge } \\
4.22\end{array}$ \\
\hline 2 & $\begin{array}{l}\text { Usually, the basic ingredients in making Kebebe will } \\
\text { be mixed together with shrimp paste and bird's eye } \\
\text { chilies }\end{array}$ & $\begin{array}{l}\text { Some } \\
\text { K'ledge } \\
4.84\end{array}$ & $\begin{array}{l}\text { Some } \\
\text { K'ledge } \\
4.78\end{array}$ \\
\hline 3 & $\begin{array}{l}\text { Usually, Kebebe is prepared with community working } \\
\text { together in preparation for feast and iftar events }\end{array}$ & $\begin{array}{l}\text { Some } \\
\text { K'ledge } \\
4.47\end{array}$ & $\begin{array}{l}\text { Some } \\
\text { K'ledge } \\
4.48\end{array}$ \\
\hline 4 & $\begin{array}{l}\text { The preparation of Kebebe will be more attractive } \\
\text { when it is served in banana leaves and banana flower }\end{array}$ & $\begin{array}{l}\text { Some } \\
\text { K'ledge } \\
4.26\end{array}$ & $\begin{array}{l}\text { Some } \\
\text { K'ledge } \\
4.30\end{array}$ \\
\hline 5 & $\begin{array}{l}\text { Consuming Kebebe can overcome nauseating feeling } \\
\text { other than its ability to cure lethargy, sickness and } \\
\text { bitterness taste in the mouth }\end{array}$ & $\begin{array}{l}\text { Some } \\
\text { K'ledge } \\
4.26\end{array}$ & $\begin{array}{l}\text { Some } \\
\text { K'ledge } \\
4.56\end{array}$ \\
\hline
\end{tabular}

\subsubsection{Partitioning of Age Category with Level of Knowledge on KEBEBE as the Traditional Food of Hulu Perak}

On partitioning of age category with level of knowledge on Kebebe as the traditional food of Hulu Perak, all the respondents in the age category of 18 to 24,25 to 29,40 to 49 , and those over 50 years old categories indicated that they had some knowledge in that (1) the jackfruit, banana, guava, pineapple, cermai, cedung, belimbing buluh and kelempong were some of the ingredients used in making Kebebe, (2) the basic ingredients in making Kebebe would be that they would usually be mixed together with shrimp paste and bird's eye chilies, (3) Kebebe was usually prepared with community working together in preparation for feast and iftar events, (4) the preparation of Kebebe would be more attractive when it was served in banana leaves and banana flower, and that (5) consuming Kebebe could overcome nauseating feeling other than its ability to cure lethargy, sickness and bitterness taste in the mouth. There were some differences in responses for those in the age category of 30 to 39 years old where he/they indicated they he/they had full knowledge in that (1) the jackfruit, banana, guava, pineapple, cermai, cedung, belimbing buluh and kelempong were some of the ingredients used in making Kebebe, (2) the basic ingredients in making Kebebe would usually be mixed together with shrimp paste and bird's eye chilies, (3) Kebebe was usually be prepared with community working together in preparation for feast and iftar events. On the other two aspects regarding the preparation of Kebebe, it would be more attractive when it was served in banana leaves and banana flower, and the consumption Kebebe could overcome nauseating feeling other than its ability to cure lethargy, sickness and bitterness taste in the mouth, and that his/their responses were similar to that of the majority of respondents in other age categories. The following table indicated the detailed responses. 
Kebebe: The Traditional Food in the Sub-District of Lenggong, Perak

Table 10 Partitioning of Age Category with Level of Knowledge on KEBEBE as the Traditional Food

\begin{tabular}{|c|c|c|c|c|c|c|}
\hline \multirow[b]{2}{*}{ NO. } & \multirow[b]{2}{*}{ STATEMENT } & \multicolumn{5}{|c|}{ AVERAGE SCORES } \\
\hline & & $\begin{array}{c}18-24 \\
(3 \\
\text { Resp) } \\
\end{array}$ & $\begin{array}{c}25-29 \\
(3 \\
\text { Resp) } \\
\end{array}$ & $\begin{array}{c}\text { 30-39 } \\
(2 \\
\text { Resp) } \\
\end{array}$ & $\begin{array}{c}40-49 \\
(17 \\
\text { Resp) } \\
\end{array}$ & $\begin{array}{c}50+ \\
(21 \\
\text { Resp) }\end{array}$ \\
\hline 1 & $\begin{array}{l}\text { Jackfruit, banana, guava, pineapple, } \\
\text { cermai, cedung, belimbing buluh and } \\
\text { kelempong are some of the ingredients } \\
\text { used inmaking Kebebe }\end{array}$ & $\begin{array}{l}\text { Some } \\
\text { K'ledge } \\
4.00\end{array}$ & $\begin{array}{l}\text { Some } \\
\text { K'ledge } \\
4.75\end{array}$ & $\begin{array}{l}\text { Full } \\
\text { K'ledge } \\
5.00\end{array}$ & $\begin{array}{l}\text { Some } \\
\text { K'ledge } \\
4.36\end{array}$ & $\begin{array}{l}\text { Some } \\
\text { K'ledge } \\
4.43\end{array}$ \\
\hline 2 & $\begin{array}{l}\text { Usually, the basic ingredients in } \\
\text { making Kebebe will be mixed together } \\
\text { with shrimp paste and bird's eye } \\
\text { chilies }\end{array}$ & $\begin{array}{l}\text { Some } \\
\text { K'ledge } \\
4.50\end{array}$ & $\begin{array}{l}\text { Some } \\
\text { K'ledge } \\
4.47\end{array}$ & $\begin{array}{l}\text { Full } \\
\text { K'ledge } \\
5.00\end{array}$ & $\begin{array}{l}\text { Some } \\
\text { K'ledge } \\
4.93\end{array}$ & $\begin{array}{l}\text { Some } \\
\text { K'ledge } \\
4.85\end{array}$ \\
\hline 3 & $\begin{array}{l}\text { Usually, Kebebe is prepared with } \\
\text { community working together in } \\
\text { preparation for feast and iftar events }\end{array}$ & $\begin{array}{l}\text { Some } \\
\text { K'ledge } \\
4.50\end{array}$ & $\begin{array}{l}\text { Some } \\
\text { K'ledge } \\
4.50\end{array}$ & $\begin{array}{l}\text { Full } \\
\text { K'ledge } \\
5.00\end{array}$ & $\begin{array}{l}\text { Some } \\
\text { K'ledge } \\
4.65\end{array}$ & $\begin{array}{l}\text { Some } \\
\text { K'ledge } \\
4.39\end{array}$ \\
\hline 4 & $\begin{array}{l}\text { The preparation of Kebebe will be } \\
\text { more attractive when it is served in } \\
\text { banana leaves and banana flower }\end{array}$ & $\begin{array}{l}\text { Some } \\
\text { K'ledge } \\
4.00 \\
\end{array}$ & $\begin{array}{l}\text { Some } \\
\text { K'ledge } \\
4.25\end{array}$ & $\begin{array}{l}\text { Some } \\
\text { K'ledge } \\
4.00\end{array}$ & $\begin{array}{l}\text { Some } \\
\text { K'ledge } \\
4.36\end{array}$ & $\begin{array}{l}\text { Some } \\
\text { K'ledge } \\
4.35\end{array}$ \\
\hline 5 & $\begin{array}{l}\text { Consuming Kebebe can overcome } \\
\text { nauseating feeling other than its ability } \\
\text { to cure lethargy, sickness, and } \\
\text { bitterness taste in the mouth }\end{array}$ & $\begin{array}{l}\text { Some } \\
\text { K'ledge } \\
3.50\end{array}$ & $\begin{array}{l}\text { Some } \\
\text { K'ledge } \\
4.50\end{array}$ & $\begin{array}{l}\text { Some } \\
\text { K'ledge } \\
4.00\end{array}$ & $\begin{array}{l}\text { Some } \\
\text { K'ledge } \\
4.29\end{array}$ & $\begin{array}{l}\text { Some } \\
\text { K'ledge } \\
4.38\end{array}$ \\
\hline
\end{tabular}

\section{SUMMARY AND CONCLUSIONS}

There were four objectives for this study, and they were to identify the traditional foods in area of study, which was the Hulu Perak District, to examine the basic ingredients of the identified traditional foods. To understand the common methods of preparation and cooking of the identified traditional foods in Hulu Perak District, and to determine the level of foodways knowledge on the identified traditional foods amongst the youths in the Hulu Perak District.

The process of identifying the traditional foods of Hulu Perak was through a focus group process which comprised of 7 prominent individuals from the Hulu Perak district who were asked on the popular traditional food of the area. The list of traditional food was derived, and upon the consensus among the members of the focus group. One of the three traditional foods derived was Kebebe.

On analyzing the perception of the different demographic variables towards Kebebe, there was negligible difference on the level of knowledge between the male and female respondents for Kebebe. The findings also indicated that there was an insignificant difference on the level of knowledge among the different age categories of respondents.

The investigative study on Kebebe as a traditional food in sub-district of Lenggong in Hulu Perak had added another culinary tourism product for the Hulu Perak area and to the state of Perak as a whole. Findings from the study could help to promote the area as a traditional food area and that help to attract more culinary tourists to visit that area. This could help to ensure that the knowledge on Kebebe as a traditional food could be preserved once the results is published, and that the video could be distributed and be seen by those interested in the information. It could help to build the sense of pride for the community and for the young generation to be proud of thir heritage. The study could be used as a model for investigating the availability of traditional foods in other areas of the country and it could be the basis and 
Munira Saaidin, Erdaizzati Mohd Som, Nur Juliana Azhari, Annis Jamaluddin,

W. Eddie Azlie W. Mohd Asri and Mislan Nenin

impetus for future directions on studies of traditional foods and in diversifying the culinary tourism products.

\section{REFERENCES}

[1] Ahmad Shariff, Siti Nor Fadillah (2011) Factors influencing the level of traditional food knowledge amongst young generatio. Publication: Research Reports UiTM Institutional Repository.

[2] Allen, Gary J.; Albala, Ken (2007). The Business of Food: Encyclopedia of the Food and Drink Industries. ABC-CLIO. pp. 112-. ISBN 9780313337253. Retrieved 12 March 2013

[3] Bob McKercher, Fevzi Okumus, and Bendegul Okumus (2008) Food Tourism as a Viable Market Segment: It's All How You Cook the Numbers! Journal of Travel \& Tourism Marketing, Volume 25, 2008 - Issue 2.

[4] Bowen, R. L., \& Devine, C. M. (2011). "Watching a person who knows how to cook, you'll learn a lot".

[5] Guerrero, L., Guardia, M.D., Xicola, J., Verbeke, W., Vanhonacker, F., Zakowska-Biemans, S., Hersleth, M. (2009). Consumer-driven definatiob of traditional food products and innovation in traditionl foods. A qualitative cross-cultural study. Appetite, Vol. 52, 345-354.

[6] Kwik, J. (2008). Traditional Food Knowledge: A Case Study of an Immigrant Canadian "Foodscape". Environments Journal Volume, 36(1), 59-74.

[7] Lestari, S. (2014) The tradition to donate among women in Javanese rural areas: Reciprocity, food exchange and monetization. Vol.6(7), pp. 205-213, July 2014

[8] Linked lives, cultural transmission, and the food choices of Puerto Rican girls. [Research Support, Non-U.S. Gov't]. Appetite, 56(2), 290-298.

[9] Long, L. (2004). 'Culinary Tourism: A Folkloristic Perspective on Eating and Otherness'. In L.Long (ed) Culinary Tourism. Lexington: University Press of Kentucky: 20-50.

[10] Md Nor, Norazmir and Mohd Zahari, Mohd Salehuddin and Md Sharif, Mohd Shazali and Ishak, Noriza and Muhammad, Rosmaliza (2013). Role of traditional food knowledge(TFK) in MALAY community towards festive cuisine sustainability. Publication: Research Reports UiTM Institutional Repository.

[11] M.S. Mohd Sharif, M.S.Mohd Zahari, N. Mohd Nor, H. Mohd Salleh (2014) The adaptations of Malay Food Knowledge among Malay Generations in Kuala Lumpur, Malaysia. Taylor \& Francis Group, Londond, ISBN 978-1-138-00151-0,

[12] Stringer, R. E. (2009). The domestic foodscape of young low-income women in Montreal: Cooking practices in the context of an increasingly processed food supply. Health Education and Behaviour, 37(2), 211-226.

[13] Verbeke, W., \& López, G. P. (2005). Ethnic food attitudes and behaviour among Belgians and Hispanics living in Belgium. British Food Journal, 107, 823-840.

[14] Wahid, N.A., Mohamed, B., \& Sirat, M. (2009). Heritage food tourism: Bahulu attracts? Paper presented at the Proceedings of $2^{\text {nd }}$ National Symposium on Tourism Research, Universiti Sains Malaysia, Penang, Malaysia 18 July 2009. 